\title{
The effect of salinity gradient and heavy metal pollution on arbuscular mycorrhizal fungal community structure in some Algerian wetlands
}

\author{
Warda Sidhoum ${ }^{1,2 *}$, Kheira Bahi ${ }^{2,3}$, Zohra Fortas ${ }^{1}$ \\ ${ }^{1}$ Laboratory of Microorganisms Biology and Biotechnology, University of Oran 1 Ahmed Ben Bella, Oran, Algeria \\ ${ }^{2}$ Abdelhamid Ibn Badis University, Mostaganem, Algeria \\ ${ }^{3}$ Department of Biology, Faculty of Natural Science and Life, University of Oran 1 Ahmed Ben Bella, Oran, Algeria
}

\begin{abstract}
Algerian natural wetlands suffer from anthropogenic disturbances due to industrial development and urbanization. This study was designed to draw attention to arbuscular mycorrhizal fungi (AMF) distribution and community assemblages following heavy metal and salinity concentrations in two wetlands subjected to domestic and industrial effluents. Rhizospheric soil and roots of 18 plant species were collected in two wetlands along a decreasing salinity gradient. The results showed that $72.72 \%$ of plant species exhibit an association within arbuscular mycorrhizas (AM), and 36.36\% a dual association between AM and dark septate endophytes (DSE). A total of 33 AMF morphospecies were distinguished on the basis of morphological criteria dominated by taxa belonging to Glomeraceae and Acaulosporaceae. Soil contamination was investigated by determining metallic trace elements (MTE) (Cd, $\mathrm{Cu}, \mathrm{Ni}, \mathrm{Pb}, \mathrm{Cr}$ and $\mathrm{Zn}$ ) using an atomic absorption spectrophotometer. Values of the pollution index revealed wetlands that were particularly polluted by lead. Two-way ANOVA showed significant variations in metal content among sampling locations and transects. Principal component analysis showed that species richness, and mycorrhizal frequency were slightly affected by MTE. This opens possibilities for their utilization in polluted soil remediation.
\end{abstract}

Keywords: Dark septate endophytes, metallic trace elements, mycorrhizal association, saline wetlands, soil pollution

\section{Introduction}

Oran is located in the north-west of Algeria, and constitutes a wetland complex of eight zones, four of which are classified as of International Importance. Great Sebkha and Macta (since 2001), Telamine Lake (LT) and les Salines d'Arzew (since 2004), while others, though not be classified as Ramsar, have nonetheless received attention from the Ramsar Convention (Chenchouni and Si Bachir 2010). These wetlands are ecologically important ecosystems, providing important winter grounds for several world populations of endangered bird species. In particular, species belonging to the Anas and Tadorna orders, overwinter in significant numbers in these areas (Boucheker et al. 2011, Samraoui et al. 2015).

The wetland soils are mostly Solonchak types, containing large amounts of exchangeable sodium and soluble salts (Benziane 2013). These habitats are characterized by the presence of flooded or water saturated soils for at least part of the growing season. These natural hydrosystems have halophylic plants, such as Amaranthaceae (Ghodbani and Amokrane 2013, Megharbi et al. 2016). However, these ecosystems can be modified by various factors, among them aridity causing changes in soil properties and trace element pollution. This is due to human activities, including, urbanization processes, domestic sewage discharges, livestock wastewater and industrial effluent (Bouldjedri et al. 2011, Domínguez-Beisiegel et al. 2016).

Several studies have shown that arbuscular mycorrhizal fungi (AMF) exist in the roots of wetland plants and woody species grown on flooded soils (D'Souza and Rodrigues 2013), in aquatic macrophytes, freshwater wetland plant communities and salt marshes (Xu et al. 2016). It has also been shown that AM fungal diversity in wetlands is com-

\footnotetext{
* Corresponding author e-mail: sidhoumwarda@yahoo.fr
} 
parable to that of most terrestrial ecosystems and for the growth and development of wetland plant species, and thus AM fungi are functionally essential (Tuheteru et al. 2015).

The primary abiotic factors: soil flooding, nutrient, oxygen availability, salinity, and high levels of heavy metals in soil strongly affect the abundance and distribution of AM fungi in aquatic ecosystems (Millar and Bennett 2016). As previously reported, the intraradical and extraradical mycelia of metallic stress adapted AMF isolates are capable of sequestering heavy metals and alleviating metal toxicity to plants (Cabral et al. 2015). This indicates that these fungi have evolved a tolerance to metallic trace elements (MTE), and play a role in the phytoremediation of metal polluted sites, even in polluted aquatic and semi-aquatic habitats (Wężowicz et al. 2015).

A number of surveys on AMF associated with wetland plants have been performed in order to investigate their diversity and colonization potential (D'Souza and Rodrigues 2013, Kumar and Muthukumar 2014) along a soil hydrological gradient (de Marins et al. 2009, Miller and Bever 1999, Turner et al. 2000), salinity (Roda et al. 2008, Saint-Etienne et al. 2006, Yang et al. 2010), or nutrient content (Cornwell et al. 2001, Jayachandran and Shetty 2003). There has been a small amount of research focused on AMF communities in MTE polluted wetlands (Carrasco et al. 2006, Ban et al. 2017), but there has been no report of the simultaneous effect of salinity and heavy metals on AMF distribution in wetland habitats. The present study, therefore, was aimed at evaluating the AM fungal diversity in heavy metals polluted saline wetlands and at adding to knowledge on these populated areas with heterogeneous plant species that have rarely been considered mycorrhizal, as well as at exploring the impact of soil salinity gradient and trace element pollution on AMF community structures.

\section{Materials and methods}

\section{Study area}

This survey was carried out in two wetlands located in Oran city (western region of Algeria), namely Telamine Lake (LT) (35'42'50"N 0²3'30"W) located in the district of Gdyel (eastern Oran) at $7 \mathrm{~km}$ from Hassi Amer industrial Zone II. Dayet Morsli (DM) (3539'58”N 0³6'27”W) located in EsSénia district in the south of Oran at a distance of $2 \mathrm{~km}$ north of the industrial Zone I of Es-Sénia. The altitude ranged between 50 and $87 \mathrm{~m}$ a.s.l. The regional climate is of the semiarid Mediterranean type characterized by a cold and rainy winter followed by a hot dry summer spread over 4 to 6 consecutive months where the average temperature varies between $14.1^{\circ} \mathrm{C}$ and $22.5^{\circ} \mathrm{C}$ and precipitation varies between 250 and $400 \mathrm{~mm}$ per year.

\section{Sampling}

The investigations were conducted at each site (LT and DM) along four transects $200 \mathrm{~m}$ long and $10 \mathrm{~m}$ wide. Starting from the wetland water edge to the periphery. Each tran- sect was divided into three plots according to the salinity gradient and plant distribution: from $0 \mathrm{~m}$ (where no vegetation was present) to $30 \mathrm{~m}$, and electrical conductivity (EC)

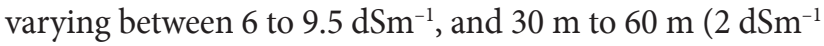
$\left.<\mathrm{EC}<6 \mathrm{dSm}^{-1}\right)$, and more than $60 \mathrm{~m}\left(\mathrm{EC}<2 \mathrm{dSm}^{-1}\right)$.

A total of 24 soil samples representing 12 plots in each wetland were selected. From each plot, one soil sample was used for chemical analysis. Also, five replicates per plant species of rhizospheric soil and roots of dominant plant species were sampled as well. In order to establish AM fungal diversity, about $500 \mathrm{~g}$ of rhizospheric soil was collected from topsoil (10 to $30 \mathrm{~cm}$ depth), put into plastic bags, air-dried and stored at room temperature at the laboratory until use.

Plant species encountered were recorded, with their relative abundances estimated visually and rated on a scale of $\mathrm{I}$ (very rare) to $\mathrm{V}$ (very abundant) (Bradai et al. 2015). The determination of herbarium specimens for floristic inventory was carried out using Flore de l'Afrique du Nord (Maire 1958-1976), and a previous study used as a reference on saline wetlands vegetation of Oran region (Quézel and Simonneau 1960). Plant nomenclature was brought up to date according to the Synonymic Index proposed by Dobignard and Chatelain (2010-2013).

\section{Chemical analyses of soil}

Soil samples were dried at room temperature and sieved in a $2 \mathrm{~mm}$ mesh size sieve. Dried soil samples were analyzed for $\mathrm{pH}$ and electrical conductivity on 1:2.5 (soil: distilled water suspension ratio) (Mathieu and Pieltain 2003).

Trace elements were extracted according to the aqua regia method ISO 11466: 1995 . About $0.5 \mathrm{~g}$ of dried soil at $105{ }^{\circ} \mathrm{C}$ was digested in $10 \mathrm{~mL}$ of freshly prepared aqua regia solution $\left(1 / 3\right.$ of $\mathrm{HNO}_{3}$ and $\left.\mathrm{HCl}, \mathrm{v} / \mathrm{v}\right)$ on a hotplate for 2 $\mathrm{h}$ at $100{ }^{\circ} \mathrm{C}$. After evaporation to near dryness, the extracts were cooled to room temperature before being filtered. The filtrates were further transferred to $25 \mathrm{~mL}$ volumetric flasks and brought to volume with distilled water, then stored at $4{ }^{\circ} \mathrm{C}$ until the spectrophotometric measurement using the AAS Shimadzu AA-7000 atomic absorption flame emission spectrophotometer.

\section{Soil pollution index}

Multiple contaminations by metallic trace elements increase soil toxicity. Soil pollution index is the criterion that allows us to evaluate soil toxicity, to classify the soil contamination and to assess potential ecological risk (Müller 1979, Belabed et al. 2014). This index is calculated by the ratio of heavy metal content in the soil (ppm) based on the corresponding values, according to the following formula proposed by Kloke (1979):

$$
\mathrm{PI}=\frac{\frac{\mathrm{Cd}}{2}+\frac{\mathrm{Cu}}{100}+\frac{\mathrm{Pb}}{100}+\frac{\mathrm{Zn}}{300}+\frac{\mathrm{Cr}}{150}+\frac{\mathrm{Ni}}{50}}{6}
$$

where PI $>$ 1indicates that the soil is polluted. 


\section{Assessment of AMF and DSE colonization}

Young roots (with root tips) were washed in tap water to remove soil particles, and then fixed in FAA formalin, glacial acetic acid, and ethanol (1:1:18, v/v/v). Roots were washed several times in tap water, cleared in $10 \%(\mathrm{w} / \mathrm{v}) \mathrm{KOH}$ while heating to approximately $90{ }^{\circ} \mathrm{C}$ for $1 \mathrm{~h}$, acidified in $10 \%$ lactic acid, and stained with $0.1 \%$ trypan blue in lactophenol at $90^{\circ} \mathrm{C}$ for $1 \mathrm{~h}$, according to a modified method of Phillips and Hayman (1970). For each root system, AMF colonization was estimated by optical microscopy (Olympus CX22) from 50 root fragments of approximately $1 \mathrm{~cm}$ in length. Mycorrhizal development was evaluated according to the method of Trouvelot et al. (1986), and expressed as mycorrhizal frequency (f\%), intensity of colonization (M\%), mycorrhizal intensity of colonized root fragments ( $\mathrm{m} \%)$, arbuscules abundance (A\%) and arbuscules abundance of colonized root fragments $(\mathrm{a} \%)$. In the case of DSE colonization, microsclerotia and hyphae were scored collectively, and the frequency of DSE occurrence in roots (DSE\%) was calculated as the ratio between colonized root fragments by DSE and the total number of examined root fragments.

\section{Isolation and taxonomic identification of AM fungal spores}

The plants were carefully dug out from the soil and the majority of bulk soil was manually removed from the roots. Only the soil closely attached to the root system was analyzed. AM fungal spores were isolated via wet sieving (Gerdemann and Nicolson 1963) followed by soil centrifugation (1398 × $g$ during 10 minutes at room temperature) in 50\% sucrose solution and filtration (mesh size $40 \mu \mathrm{m}$ ) (Brundrett et al. 1996). Intact, noncollapsed spores, with cytoplasmic content were separated into groups according to general morphological similarities recorded under a stereomicroscope (Leica EZ4HD), and the diameter of spores was measured. Also, permanent slides of all spores were prepared with the use of a drop of polyvinyl alcohol/lactic acid/glycerol (PVLG) mixed with Melzer's reagent $(1: 1, \mathrm{v} / \mathrm{v})$ on a slide. Species identification was based on the examination of spore morphological and subcellular characteristics. Obtained results were compared to the descriptions of Oehl et al. (2011), and Redecker et al. (2013); other available descriptions are found on the sites www.agro.ar.szczecin.pl/ jblaszkowski/ and https://invam.wvu.edu/, while the nomenclature employed follows that used by the Mycobank (www.mycobank.org).

\section{Statistical analysis}

Ecological measures of diversity used to describe the structure of AMF communities included spore density (number of spores in $100 \mathrm{~g}$ of soil), species richness (number of identified AMF species per soil sample), relative abundance (RA), isolation frequency (IF), Shannon's diversity index (H'), evenness (E), Simpson's index of dominance (D), and Sorensen's coefficient (Cs) (Simpson 1949).

The relative abundance refers to how common or rare a species is relative to other, and it was calculated from the formula:

$$
\mathrm{RA}=\frac{\text { spore number of a species }(\text { genus })}{\text { total number of identified spore samples }} \times 10
$$

Isolation frequency was calculated following the formula:

$$
\mathrm{IF}=\frac{\text { number of soil samples where a species (genus) }}{\text { total number of soil samples }}
$$

The Shannon diversity index is a mathematical measure of species diversity in a community. $\mathrm{H}^{\prime}$ value was calculated according to the formula: $H^{\prime}=-\sum \mathrm{Pi} \ln \mathrm{Pi}$, where $\mathrm{Pi}$ is the relative abundance of each identified species per sampling site and calculated by the following formula $\mathrm{Pi}=\mathrm{ni} / \mathrm{N}$, where ni is the number of spores of a species and $\mathrm{N}$ is the total number of all identified spores. The evenness also called "equitability", refers to the homogeneity of the species, $0<\mathrm{E}<1, \mathrm{E}=$ 1 means that all species have the same frequency. It was calculated according to the formula $\mathrm{E}=\frac{H^{\prime}}{H^{\prime} \max }$, where $H_{\max }^{\prime}$ is the maximal $H^{\prime}$ that can be determined by the following formula: $H_{\max }^{\prime}=\ln \mathrm{S}$, where $\mathrm{S}$ is the total number of identified species per sampling site. Simpson's index of dominance (D) measuring the probability that two randomly selected individuals in a community belong to the same species $(0<\mathrm{D}<1)$ was calculated from the formula: $\mathrm{D}=\sum[\mathrm{ni}(\mathrm{ni}-1) / \mathrm{N}(\mathrm{N}-1)]$. Sorensen's coefficient was used to compare the similarity of two sites, and was calculated following the formula: $\mathrm{Cs}=2 \mathrm{j} /$ $(a+b)$, where $a$ or $b$ is the total number of identified species per sampling site and $\mathrm{j}$ is the number of identified species common to both sites. We determined the dominant AMF species with respect to the IF $>50 \%$ and the RA $>5 \%$.

All statistical analyses were performed using the SPSS software package (version 23.0). The data were analyzed by two-way ANOVA with site (geographical location of the wetlands) and plots (the position in the transect) as main factors. Multiple mean comparisons were performed using Tukey's HSD post hoc test at the 0.05 level of probability. A principal component analysis (PCA) was performed in order to verify the environmental variables that best explain AMF community structure. Because the variables were measured in different units, a correlation test was used (all variables were normalized using division by their standard deviations).

\section{Results}

\section{Species composition and abundance}

The floristic survey on sites reveals the presence of a variable phytodiversity comprising 46 vascular plant species ( 34 in DM, and 28 in LT) belonged to 44 genera and 21 families, thus indicating that Dayet Morsli was the most diversified site (Tab. 1). Moreover, flora was characterized by the dominance of taxa belonging to the families Amaranthaceae (26.47\% in DM and 25\% in LT) and Asteraceae (23.52\% in DM and $17.85 \%$ LT), followed in DM by Poaceae (17.64\%), Solanaceae $(8.82 \%)$, Malvaceae, Liliaceae $(5.88 \%)$, while $2.94 \%$ of the remaining species belonged to other families. 
Tab. 1. Abundances of plant species in the wetlands Dayet Morsli and Telamine Lake, Algeria, and their accession numbers at the Plant Ecology Laboratory Herbarium of the University Oran 1 Ahmed Ben Bella, Oran, Algeria. Abundance classes: I - very rare, II - rare, III - occasional, IV - frequent, V - abundant (Bradai et al. 2015). / = no accession number in the herbarium.

\begin{tabular}{|c|c|c|c|c|}
\hline Family & Plant species & Herbarium accession no. & Dayet Morsli & Telamine Lake \\
\hline Aizoaceae & Mesembryanthemum crystallinum $\mathrm{L}$. & 00790 & II & I \\
\hline Amaranthaceae & Chenopodium album $\mathrm{L}$. & 00739 & II & I \\
\hline Amaranthaceae & Arthrocnemum macrostachyum (Monic.) K.Koch & 00745 & III & III \\
\hline Amaranthaceae & Atriplex halimus L. & 00727 & IV & III \\
\hline Amaranthaceae & Atriplex canescens (Pursh) Nutt. & l & & III \\
\hline Amaranthaceae & Sarcocornia perennis (Mill.) A.J.Scott & 00747 & III & III \\
\hline Amaranthaceae & Salicornia patula Duval-Jouve & 00746 & II & III \\
\hline Amaranthaceae & Suaeda vera Forssk. ex J.F.Gmel. & 00767 & III & IV \\
\hline Amaranthaceae & Atriplex prostrata DC. & 00720 & I & . \\
\hline Amaranthaceae & Beta macrocarpa Gus. & 00732 & I & . \\
\hline Apiaceae & Daucus carota subsp. carota (L.) Thell. & 01924 & . & III \\
\hline Apiaceae & Smyrnium olusatrum L. & 01993 & & II \\
\hline Arecaceae & Chamaerops humilis L. & 00449 & I & I \\
\hline Asteraceae & Scolymus maculatus L. & 03033 & I & I \\
\hline Asteraceae & Calendula stellata Cav. & 02824 & I & II \\
\hline Asteraceae & Centaurea pullata L. & 02966 & I & II \\
\hline Asteraceae & Glebionis coronaria $(\mathrm{L}$.) Spach & 02878 & I & \\
\hline Asteraceae & Limbarda crithmoides subsp. longifolia (Arcang.) Greuter & 02764 & & I \\
\hline Asteraceae & Dittrichia viscosa (L.) Greuter. & 02763 & I & . \\
\hline Asteraceae & Silybum marianum (L.) Gaertn. & 02941 & II & \\
\hline Asteraceae & Taraxacum erythrospermum Andrz. ex Besser & 03096 & & II \\
\hline Brassicaceae & Sinapis arvensis L. subsp. arvensis & 01146 & I & I \\
\hline Cucurbitaceae & Ecballium elaterium (L.) A.Rich. & 02682 & I & \\
\hline Cynomoriaceae & Cynomorium coccineum (L.) subsp. coccineum & 01873 & & I \\
\hline Fabaceae & Trifolium tomentosum L. & 01446 & I & . \\
\hline Joncaceae & Juncus maritimus Lamk. & 00461 & & I \\
\hline Lamiaceae & Marrubium vulgare L. & 02346 & I & II \\
\hline Liliaceae & Asphodelus tenuifolius Cav. & 00496 & I & \\
\hline Liliaceae & Asphodelus ramosus $\mathrm{L}$. & 00493 & & II \\
\hline Malvaceae & Malva sylvestris $\mathrm{L}$. & 01819 & II & I \\
\hline Malvaceae & Lavatera multiflora (Cav.) Soldano et al. & 01826 & I & \\
\hline Oxalidaceae & Oxalis pes-caprae $\mathrm{L}$. & 01683 & & II \\
\hline Plantaginaceae & Plantago lagopus L. & 02583 & I & . \\
\hline Poaceae & Avena sterilis L. & 00252 & I & 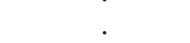 \\
\hline Poaceae & Hordeum murinum L. subsp. Glaucum (Steud.) Tzvelev & 00386 & II & II \\
\hline Poaceae & Anisantha madritensis (L.) Nevski & 00345 & II & \\
\hline Poaceae & Hordeum maritimum With. subsp. Maritimum & I & & I \\
\hline Poaceae & Phalaris canariensis $\mathrm{L}$. & 00143 & II & . \\
\hline Poaceae & Phragmites australis subsp. altissima (Benth.) & 00227 & I & . \\
\hline Primulaceae & Lysimachia arvensis (L.) U. Manns \& Andreb. & 02112 & I & 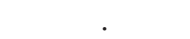 \\
\hline Rhamnaceae & Ziziphus lotus (L.) Desf. & 01802 & 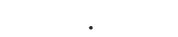 & II \\
\hline Solanaceae & Datura stramonium L. & 02437 & I & . \\
\hline Solanaceae & Nicotiana glauca Graham & 02426 & I & . \\
\hline Solanaceae & Solanum indicum L. & 1 & I & . \\
\hline Tamaricaceae & Tamarix sp. & 1 & & I \\
\hline Urticaceae & Urtica pilulifera L. & 00698 & I & I \\
\hline
\end{tabular}

On the other hand, in LT the Asteraceae were followed by Poaceae and Apiaceae (each represented with $7.14 \%$ of the species), and the rest of surveyed plant families (each represented with $3.57 \%$ of the species).

\section{Soil chemical properties}

Results of soil physicochemical analyzes (Tab. 2) revealed an average EC value $4.72 \mathrm{dSm}^{-1}$ in LT $\left(2.07-7.98 \mathrm{dSm}^{-1}\right)$ and 4.42 in DM (0.2-9.5 dSm $\left.{ }^{-1}\right)$, in addition to a slightly alkaline $\mathrm{pH}$ varying from 7.3 to 8.5 in $\mathrm{DM}$ and from 7.33 to 8.31 in LT.

Overall, the results showed higher levels of heavy metals in DM topsoils than those found in LT. These values are greater than the maximum concentration foreseen in the environmental soil quality guidelines AFNOR NFU 44-041.
A high level of $\mathrm{Pb}$ was found at both sites, while $\mathrm{Cd}$ and $\mathrm{Cr}$ were present in DM only. The pollution index in DM is considerably greater with values exceeding 1 , indicating that $\mathrm{DM}$ is a moderately polluted site.

Two-way ANOVA showed significant differences between the investigated sites along transects in salinity degree (EC) $(\mathrm{P}<0.001), \mathrm{Cr}(\mathrm{P}<0.001)$, as well as $\mathrm{Zn}(\mathrm{P}<0.05)$ and $\mathrm{Cu}$ concentrations $(\mathrm{P}<0.01)$, which significantly and steadily decreased from sea to inland regions.

Also, significant differences were noticed between wetland sites for all MTE concentrations (except Zn), pollution index, and salinity $(\mathrm{Ni}, \mathrm{Cr}, \mathrm{Cu}$ and $\mathrm{PI}$ at $\mathrm{P}<0.001, \mathrm{~Pb}$ $(\mathrm{P}<0.01)$, Cd and EC $(\mathrm{P}<0.05))$. No significant effect was observed in the interaction (site ${ }^{*}$ plot) on $\mathrm{Zn}$ and $\mathrm{Ni}$. The obtained results highlight the effect of distance from water which has a very important role in soil MTE concentration. 


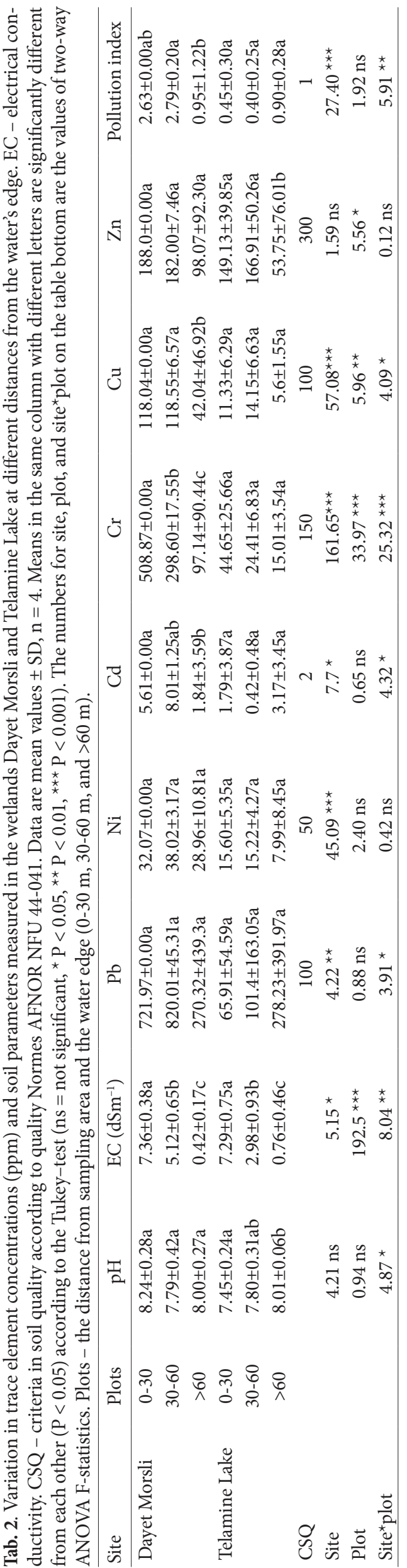

\section{Fungal root colonization}

Arbuscular mycorrhizae were observed in $72.72 \%$ of plant species since the dual association between AM fungi and DSE was found in $36.36 \%$ of plant species. One species (Asphodelus tenuifolius) showed AM, DSE, and ectomycorrhizae (Tab. 3). No AM was noted in roots of some species: Mesembryanthemum crystallinum, Arthrocnemum macrostachyum, Salicornia patula and Tamarix gallica. The mean AM frequen$\mathrm{cy}(\mathrm{f} \%)$ varied with particular species, ranging from $10 \%$ (Beta macrocarpa and Sarcocornia perennis) to 100\% (Calendula stellata and Marrubium vulgare). AM colonization intensity (M\%) varied from $0.69 \%$ in Sarcocornia perennis to $67.62 \%$ in Centaurea pullata. The mean arbuscule richness (A\%) was also diverse and being lowest in all Amaranthaceae, in particular, Atriplex canescens ( $0.93 \%$ ) and highest in Asteraceae, i.e. in Centaurea pullata (60.61\%) (Tab. 3). Arum type morphology was present in $76.47 \%$ of mycorrhized plants, $11.76 \%$ in Paris type morphology and the rest were not identified as AM morphology, their association being generally characterized by hyphal proliferation with few arbuscules.

DSE was found in $54.54 \%$ of collected plants, although the DSE occurrence frequency in roots was high in the case of several taxa (Tab. 3). Several forms of mycelia were encountered in both the outer cortex and the rhizoderm. Here, brownish, thick mycelium $(4-5 \mu \mathrm{m})$ was developed into microsclerotia around the central cylinder or thin mycelium $(2 \mu \mathrm{m})$ stained with trypan blue-lacking dark pigmentations. They subsequently formed hyphal complexes in cortical cells or aggregates to form a puzzle or brain-like microsclerotium and thick-walled mycelium for plate lobed and unlobed hyaline mycelium.

Other fungal endophytes were noted: the remaining Olpidium spp. (Chytridiomycota) spores found in Asphodelus tenuifolius, Beta macrocarpa, and Atriplex halimus rhizodermis and outer cortex. Chlamydospore-like structures in Beta macrocarpa roots and fine hyphae with fanshaped branches and Glomus tenue swellings (Glomeromycota) were discovered in A. halimus roots.

\section{AMF community composition and diversity}

On the basis of morphological criteria, 33 morphospecies were distinguished from analyzed site samples (Tab. 4). AM community was characterized by the presence of several taxa belonging to: Glomeraceae (16 taxa) represented by five genera, Glomus (5 spp.), Rhizoglomus (4 spp.), Funneliformis (3 spp.), Sclerocystis (2 spp.) and Septoglomus (1 sp.), Acaulosporaceae (Acaulospora 10 spp.), Diversisporaceae (Diversispora 2 spp. and Tricispora 1 sp.), Claroideoglomeraceae (Claroideoglomus 2 spp.), Archaeosporaceae (Archaeospora 1 sp.), Paraglomeraceae (Paraglomus 1 sp.), and Ambisporaceae (Ambispora 1 sp.). However, fourteen morphospecies remained unidentified since their morphological characteristics did not fit with any description of known species.

Species richness of the sampled plant species varied in the rhizospheric soils, with maximum levels in DM (28 species) followed by LT (20 species). Fourteen species are classified as general and were found at all sites. A total of 12 species were classified as exclusive. There were ten only in DM (Acaulospora cf. collicosa, A. alpina, A. rehmii, Diversispora sp. 1, Divercispora tortuosa, Tricispora nevadensis, Glomus macrocarpum, G. diaphanum, Sclerocystis rubiformis and Rhizoglomus sp. 3) and 2 AMF species that were restricted to LT (Acaulospora sp. 3 and G. lamellosum).

The highest number of spores in both sites belonged to Acaulosporaceae (Tab. 4), followed by Archaeosporaceae and Glomeraceae. In DM the Glomeraceae were dominated by Rhizoglomus (6.74\%), Glo- 
Tab. 3. Fungal root endophyte colonization of plant species in the wetlands Dayet Morsli (DM) and Telamine Lake (LT). Arbuscular mycorrhizal types: P - Paris-type, A - Arum-type, -: not determined, NM - non mycorrhizal, E - ectomycorrhizal, Mycorrhizal frequency $\mathrm{f} \%$ - the ratio between colonized root fragments by Arbuscular mycorrhizal fungi and the total number of examined root fragments, $\mathrm{m} \%$ - mycorrhizal intensity of colonized root fragments, $\mathrm{M} \%$ - the colonization intensity in all root system, a\% - arbuscule abundance of colonized root fragments, A\% - arbuscule abundance of all root system, DSE\% - the ratio between colonized root fragments by Dark septate endophytes and the total number of examined root fragments.

\begin{tabular}{|c|c|c|c|c|c|c|c|c|c|}
\hline Family & Plant species & Location & AM type & $\begin{array}{l}\text { Mycorrhizal } \\
\text { frequency f\% }\end{array}$ & $\mathrm{M} \%$ & $\mathrm{~m} \%$ & $\mathrm{a} \%$ & $\mathrm{~A} \%$ & $\begin{array}{c}\text { DSE } \\
\%\end{array}$ \\
\hline Aizoaceae & Mesembryanthemum crystallinum & $\mathrm{DM}$ & NM & 0 & 0 & 0 & 0 & 0 & 70 \\
\hline \multirow{10}{*}{ Amaranthaceae } & Arthrocnemum macrostachyum & $\mathrm{DM}$ & $\mathrm{NM}$ & 0 & 0 & 0 & 0 & 0 & 0 \\
\hline & Atriplex canescens & LT & $\mathrm{A}$ & 48 & 7.14 & 14.88 & 13.07 & 0.93 & 8 \\
\hline & Atriplex halimus & LT & A & 58.49 & 18.74 & 32.03 & 11.54 & 2.16 & 13.2 \\
\hline & Atriplex halimus & $\mathrm{DM}$ & A & 57.25 & 21.63 & 38.44 & 10 & 2 & 12 \\
\hline & Beta macrocarpa & $\mathrm{DM}$ & - & 10 & 3.4 & 5.63 & 5.76 & 0.2 & 72 \\
\hline & Salicornia patula & $\mathrm{DM}$ & NM & 0 & 0 & 0 & 0 & 0 & 0 \\
\hline & Sarcocornia perennis & LT & - & 1.82 & 0.02 & 1 & 0 & 0 & 7.27 \\
\hline & Sarcocornia perennis & $\mathrm{DM}$ & - & 10 & 0.69 & 1.35 & 0 & 0 & 28 \\
\hline & Suaeda vera & LT & A & 36 & 8.16 & 22.67 & 21.69 & 1.77 & 4 \\
\hline & Suaeda vera & $\mathrm{DM}$ & A & 76.19 & 28.9 & 39.16 & 41.26 & 11.93 & 0 \\
\hline \multirow[t]{6}{*}{ Asteraceae } & Silybum marianum & $\mathrm{DM}$ & A & 93.55 & 8.53 & 8.93 & 34.9 & 2.92 & 0 \\
\hline & Calendula stellata & $\mathrm{DM}$ & $\mathrm{P}$ & 100 & 61.27 & 61.27 & 85.26 & 52.25 & 0 \\
\hline & Centaurea pullata & LT & A & 98 & 67.62 & 69 & 89.64 & 60.61 & 46 \\
\hline & Dittrichia viscosa & $\mathrm{DM}$ & $\mathrm{P}$ & 89.66 & 56.12 & 62.6 & 81.8 & 45.91 & \\
\hline & Limbarda crithmoides subsp. longifolia & LT & A & 87.88 & 31.03 & 35.31 & 93.38 & 28.98 & 12 \\
\hline & Scolymus maculates & $\mathrm{DM}$ & A & 45 & 13 & 28.89 & 64.67 & 8.41 & 0 \\
\hline Juncaceae & Juncus maritimus & $\mathrm{LT}$ & A & 60 & 9.06 & 15.1 & 3.89 & 0.35 & 0 \\
\hline Lamiaceae & Marrubium vulgare & LT & A & 98.08 & 48.67 & 49.3 & 88.14 & 42.8 & 0 \\
\hline \multirow[t]{2}{*}{ Liliaceae } & Marrubium vulgare & $\mathrm{DM}$ & A & 100 & 52.21 & 52.21 & 70.76 & 36.94 & 0 \\
\hline & Asphodelus tenuifolius & $\mathrm{DM}$ & $\begin{array}{l}\mathrm{E} \\
\mathrm{A}\end{array}$ & $\begin{array}{l}10 \\
2.5\end{array}$ & 0 & 0 & 0 & 0 & 27.5 \\
\hline Tamaricaceae & Tamarix sp. & LT & NM & 0 & 0 & 0 & 0 & 0 & 30 \\
\hline
\end{tabular}

mus (1.66\%), Funnelifomis (1.21\%), Septoglomus (0.71\%), and Sclerocystis (0.34\%), while Funnelifomis (5.98\%), Septoglomus (3.45\%), Glomus (0.37\%), Rhizoglomus (1.12\%), and Sclerocystis $(0.45 \%)$ dominated in LT. The other families were not equally present in the studied sites. In DM, Claroideoglomeraceae (2.29\%) were more dominant than Ambisporaceae (1.94\%) and Diversisporaceae (1.6\%), but in LT, we found Paraglomaceae (1.02\%) then Ambisporaceae (0.6\%). Spore density is higher in LT (1077.09/100 g of soil) than that seen in DM (640/100 g of soil). Based on relative abundance and isolation frequency, six species were dominant in DM (Acaulospora thomii, A. cf. morrowae, A. rehmii, A. leavis, A. melea and Archaeospora undulata), whereas only three dominated in LT: A. thomii, A. leavis and Ar. undulata (Tab. 4).

On the other hand, a few AMF species had low relative abundances but high isolation frequency, such as the species in DM: A. leavis (6.96\% RA, 100\% IF), A. melea (6.18\% RA $100 \%$ and $80 \%$ IF), and Tricispora nevadensis (1.23\% RA and $71.42 \%$ IF). RA of Claroideoglomus claroideum is 2.29 $\%$ in DM and 2.75 in LT, while IF is $85.71 \%$ in DM and 60\% LT. In addition, RA and IF of some other species in LT are: F. mosseae $(0.75 \%, 60 \%)$, Se. constrictum $(3.45 \%, 60 \%)$, and A. cf. morrowae $(4.34 \%, 60 \%)$. Two-way ANOVA showed (Table 4) the existence of significant negative effects in AM frequency $(\mathrm{P}<0.001)$, species richness $(\mathrm{P}<0.01)$, and spore density $(\mathrm{P}<0.01)$ under increasing gradient salinity (transect from water to inland), while DSE was affected positively $(\mathrm{P}<0.001)$. Moreover, only spore density was significantly different $(\mathrm{P}<0.01)$ among wetland sites. No significant effect was noted of the interaction (site ${ }^{*}$ plot) on species richness.

In general, the mean values of the Shannon index showed that DM was slightly more diversified $(1.69 \pm 0.33)$ than LT $(1.32 \pm 0.29)$. Calculation of the AM fungal community evenness indicates a more equitable distribution among AM fungal communities found in DM $(0.73 \pm 0.13)$ than that found in LT $(0.60 \pm 0.12)$. Simpson's index was higher in LT $(0.24 \pm 0.09)$ than DM $(0.19 \pm 0.06)$ reflecting a slight AM fungal species dominance among AM fungal communities. Sorensen's coefficient indicated $58 \%$ of similarity in AMF community composition between wetland sites. No significant differences were noted in diversity indices affected by sites or the (site ${ }^{\star}$ plot) interaction except for dominance in$\operatorname{dex}(\mathrm{F}=4.25, \mathrm{P}<0.05)$ which was significantly increased with salinity gradient (Tab.5).

\section{Multivariate analysis}

Eigenvalues of the two first principal components explained a large proportion (Component $143.58 \%$ and Component $222.53 \%$ ) of the total variance (Fig. 1). Component 1 was strongly correlated with heavy metals values and DSE frequency, which showed positive correlation coefficient values $(0.52$ to 0.96$)$. These metal concentrations were highly correlated with each other except for $\mathrm{Zn}(0.66 \leq \mathrm{r} \leq 0.96$; $\mathrm{P}<0.001)$. The component 2 was more correlated with $\mathrm{pH}(0.54), \mathrm{f} \%$ (0.67), EC (0.77), spore density (-0.54), species richness $(-0.75)$, and $\mathrm{Zn}(-0.63)$. 
Tab. 4. The relative abundance of arbuscular mycorrhizal fungi (AMF) isolates in the wetlands Dayet Morsli (DM) and Telamine Lake (LT). Values are expressed as mean values \pm standard deviation, $\mathrm{n}=12$. $\mathrm{RA}$ - relative abundance (\%), IF - isolation frequency (\%), SR - species richness, Average SR - the mean of species number in all plant rhizospheres for each site. SD - Spore density.

\begin{tabular}{|c|c|c|c|c|}
\hline AMF species & RA DM (\%) & IF (\%) & RA LT (\%) & IF $(\%)$ \\
\hline Acaulosporaceae & 48.11 & - & 31.86 & \\
\hline Acaulospora cf. collicosa & $0.29 \pm 0.77$ & 14.28 & - & - \\
\hline Acaulospora cf. alpina & $0.09 \pm 0.24$ & 14.28 & - & - \\
\hline Acaulospora thomii & $12.23 \pm 5.51$ & 100.00 & $15.94 \pm 3.96$ & 100.00 \\
\hline Acaulospora leavis & $6.96 \pm 4.20$ & 100.00 & $6.09 \pm 5.74$ & 60.00 \\
\hline Acaulospora melea & $6.18 \pm 5.47$ & 100.00 & $4.55 \pm 5.39$ & 80.00 \\
\hline Acaulospora tortuosa & $0.05 \pm 0.12$ & 14.28 & - & - \\
\hline Acaulospora aff. morrowae & $11.58 \pm 7.58$ & 100.00 & $4.34 \pm 3.89$ & 60.00 \\
\hline Acaulospora rehmii & $10.88 \pm 9.04$ & 85.71 & - & - \\
\hline Acaulospora sp. 1 & - & - & $0.6 \pm 0.89$ & 40.00 \\
\hline Acaulospora elegans & - & - & $0.32 \pm 0.71$ & 20.00 \\
\hline Ambisporaceae & 1.94 & - & 0.6 & \\
\hline Ambispora reticulata & $1.94 \pm 4.59$ & 28.57 & $0.6 \pm 1.34$ & 20.00 \\
\hline Archaeosporaceae & 15.67 & - & 18.39 & \\
\hline Archaeospora undulata & $15.67 \pm 15.62$ & 71.42 & $18.39 \pm 15.63$ & 80.00 \\
\hline Diversisporaceae & 1.6 & - & - & - \\
\hline Diversispora sp. & $0.09 \pm 0.24$ & 14.28 & - & - \\
\hline Diversispora tortuosa & $0.28 \pm 0.65$ & 28.57 & - & - \\
\hline Tricispora nevadensis & $1.23 \pm 1.45$ & 71.42 & - & - \\
\hline Claroideoglomeraceae & 2.29 & - & 2.75 & - \\
\hline Claroideoglomus claroideum & $2.29 \pm 2.07$ & 85.71 & $2.1 \pm 3.12$ & 60.00 \\
\hline Claroideoglomus lamellosum & - & - & $0.65 \pm 0.99$ & 40.00 \\
\hline Glomeraceae & 10.53 & - & 12.43 & \\
\hline Funneliformis caledonium & $0.38 \pm 1.00$ & 14.28 & $1.36 \pm 2.31$ & 40.00 \\
\hline Funneliformis geosporum & $0.03 \pm 0.07$ & 14.28 & $3.56 \pm 6.43$ & 40.00 \\
\hline Funneliformis mosseae & $0.80 \pm 1.24$ & 42.85 & $1.06 \pm 1.46$ & 60.00 \\
\hline Glomus achrum & - & - & - & - \\
\hline Glomus nanolumen & $0.62 \pm 0.82$ & 42.85 & $0.37 \pm 0.51$ & 40.00 \\
\hline Glomus macrocarpum & $0.64 \pm 1.70$ & 14.28 & - & - \\
\hline Glomus diaphanum & $0.25 \pm 0.67$ & 14.28 & - & - \\
\hline Glomus sp. 1 & $0.15 \pm 0.40$ & 14.28 & - & - \\
\hline Rhizoglomus microagregatum & $0.23 \pm 0.42$ & 28.57 & $0.2 \pm 0.27$ & 40.00 \\
\hline Rhizoglomus sp. 1 & $2.91 \pm 7.27$ & 28.57 & $0.42 \pm 0.93$ & 20.00 \\
\hline Rhizoglomus sp. 2 & $3.42 \pm 9.07$ & 14.28 & $0.50 \pm 1.13$ & 20.00 \\
\hline Rhizoglomus sp. 3 & $0.18 \pm 0.49$ & 14.28 & - & - \\
\hline Sclerocystis rubiformis & $0.03 \pm 0.07$ & 14.28 & - & - \\
\hline Sclerocystis sp.1 & $0.11 \pm 0.30$ & 14.28 & $0.45 \pm 0.63$ & 40.00 \\
\hline Septoglomus constrictum & $0.71 \pm 1.49$ & 28.57 & $3.45 \pm 5.30$ & 60.00 \\
\hline Paraglomeraceae & - & - & 1.02 & - \\
\hline Paraglomus sp. & - & - & $1.02 \pm 1.43$ & 40.00 \\
\hline Unidentified & $16.93 \pm 23.45$ & - & $33.81 \pm 31.81$ & - \\
\hline Total & 100 & & 100 & \\
\hline SR & 28 & & 20 & \\
\hline Average SR & $10.43 \pm 2.37$ & & $10.2 \pm 4.6$ & \\
\hline SD (100 g soil) & $640.3 \pm 269.9$ & & $1077.9 \pm 364.16$ & \\
\hline
\end{tabular}

It is worth noting that along the component 1 , the variables were clustered in three main groups. The ETM formed a distinct group within DM site and the nearest plots to the water (0-30 and 30-60). This group was negatively correlated to AMF spore density which recorded the highest level near to the water (plots 0-30 and 30-60) in Telamine Lake site. The third group gathering species richness and mycorrhizal frequency in both sites and in plot $(>60)$ was strongly reduced by both salinity and Zinc concentration.

\section{Discussion}

In this study, we present a detailed report on fungal root endophyte occurrence in eighteen plant species. Heavy metal contents in soil and their effect on the fungal composition and root colonization was also investigated.

The most represented families of the two study sites are Amaranthaceae and Asteraceae, whose dominance in wetlands was reported by several studies (Megharbi et al. 2016, Neffar et al. 2013). Halophytic species of Amaranthaceae and Asteraceae are known to be naturally better adapted to survive environmental stresses, compared to salt-sensitive crop plants commonly chosen for phytoremediation purposes as described by Manousaki and Kalogerakis (2011). Research findings suggest them as ideal candidates for phytoremediation of both saline and non-saline, heavy metal polluted soils, such as Atriplex halimus (Mesnoua et al. 2016), Mesembryanthemum crystallinum (Lutts and Lefèvre 


\section{Component Plot}

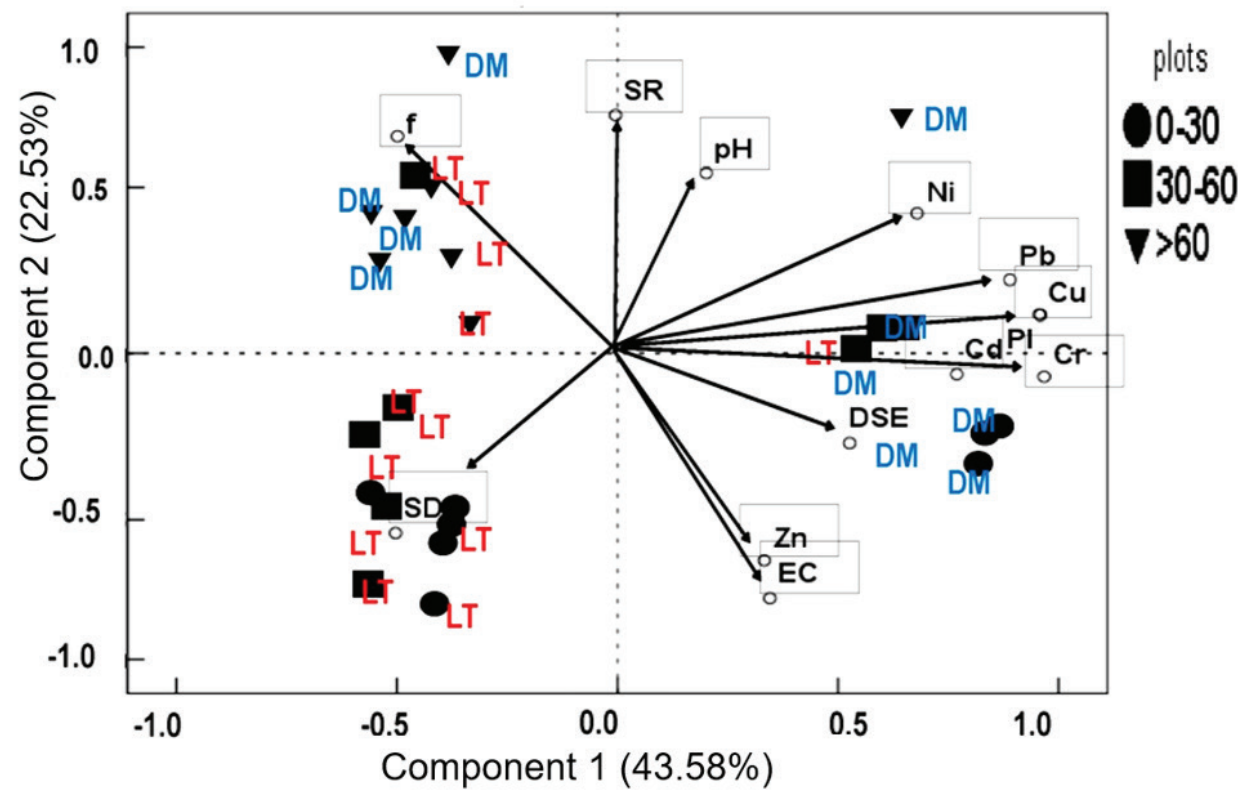

Fig. 1. Principal Component Analysis (PCA) ordination biplot of 24 soil samples in the wetlands Telamine Lake (LT) and Dayet Morsli $(\mathrm{DM})$, Algeria, and the following variables: spore density (SD), f (mycorrhizal frequency), DSE (dark septate endophytes frequency), species richness (SR), $\mathrm{pH}$, electrical conductivity (EC), pollution index (PI), and trace elements $\mathrm{Cr}, \mathrm{Cd}, \mathrm{Cu}, \mathrm{Ni}, \mathrm{Pb}, \mathrm{Zn}$.

Tab. 5. Changes in fungal colonisation, fungal spore density, species richness and diversity indexes along transects at the Dayet Morsli and Telamine Lake wetland sites. Results are expressed as mean values \pm standard deviation, $\mathrm{n}=4$. Means in the same column with different letters are significantly different from each other $(\mathrm{P}<0.05)$ according to the Tukey-test (ns = not significant, ${ }^{*} \mathrm{P}<0.05,{ }^{* *} \mathrm{P}<0.01,{ }^{* * *}$ $\mathrm{P}<0.001)$. Plots - the distance from sampling area and the water edge $(0-30 \mathrm{~m}, 30-60 \mathrm{~m}$, and $>60 \mathrm{~m})$, DSE\% - dark septate endophytes frequency, f\% - mycorrhizal frequency, SR - species richness, SD - Spore density, H' - Shannon index, D - dominance index, E - evenness. The numbers for site, plot, and site ${ }^{*}$ plot on the table bottom are F-statistics values of two-way ANOVA analysis of variance. Sites: Telamine Lake and Dayet Morsli.

\begin{tabular}{lcccccccc}
\hline Site & Plots & DSE $(\%)$ & $\mathrm{f}(\%)$ & $\mathrm{SR}$ & $\mathrm{SD}$ & $\mathrm{H}^{\prime}$ & $\mathrm{D}$ & $\mathrm{E}$ \\
\hline Dayet Morsli & $0-30$ & $70.00 \pm 0.00^{\mathrm{a}}$ & $0.00 \pm 0.00^{\mathrm{a}}$ & $9.00 \pm 0.00^{\mathrm{a}}$ & $125.00 \pm 0.00^{\mathrm{a}}$ & $1.50 \pm 0.30^{\mathrm{a}}$ & $0.25 \pm 0.03^{\mathrm{a}}$ & $0.69 \pm 0.13^{\mathrm{a}}$ \\
& $30-60$ & $12.00 \pm 0.00^{\mathrm{b}}$ & $47.08 \pm 17.39^{\mathrm{b}}$ & $10.66 \pm 3.05^{\mathrm{ab}}$ & $580.66 \pm 298.57^{\mathrm{a}}$ & $1.45 \pm 0.18^{\mathrm{a}}$ & $0.22 \pm 0.09^{\mathrm{a}}$ & $0.61 \pm 0.04^{\mathrm{a}}$ \\
& $>60$ & $2.58 \pm 6.01^{\mathrm{c}}$ & $96.63 \pm 4.79^{\mathrm{c}}$ & $13.42 \pm 1.61^{\mathrm{b}}$ & $542.85 \pm 240.17^{\mathrm{a}}$ & $1.72 \pm 0.33^{\mathrm{a}}$ & $0.18 \pm 0.05^{\mathrm{a}}$ & $0.76 \pm 0.14^{\mathrm{a}}$ \\
\hline Telamine Lake & $0-30$ & $11.86 \pm 11.63^{\mathrm{a}}$ & $50.49 \pm 17.40^{\mathrm{a}}$ & $10.00 \pm 0.63^{\mathrm{a}}$ & $1209.38 \pm 519.85^{\mathrm{a}}$ & $1.50 \pm 0.28^{\mathrm{a}}$ & $0.28 \pm 0.10^{\mathrm{a}}$ & $0.72 \pm 0.07^{\mathrm{a}}$ \\
& $30-60$ & $5.83 \pm 6.88^{\mathrm{a}}$ & $62.02 \pm 18.22^{\mathrm{a}}$ & $9.00 \pm 2.44^{\mathrm{a}}$ & $1156.66 \pm 368.16^{\mathrm{a}}$ & $1.41 \pm 0.43^{\mathrm{a}}$ & $0.18 \pm 0.05^{\mathrm{a}}$ & $0.57 \pm 0.14^{\mathrm{a}}$ \\
& $>60$ & $36.00 \pm 50.9^{\mathrm{a}}$ & $54.00 \pm 62.22^{\mathrm{a}}$ & $12.00 \pm 0.00^{\mathrm{a}}$ & $480.00 \pm 28.284^{\mathrm{a}}$ & $1.64 \pm 0.41^{\mathrm{a}}$ & $0.14 \pm 0.02^{\mathrm{a}}$ & $0.70 \pm 0.13^{\mathrm{a}}$ \\
\hline Site & & $3.27^{\text {ns }}$ & $0.85^{\mathrm{ns}}$ & $0.84^{\text {ns }}$ & $12.77^{* *}$ & $0.07^{\text {ns }}$ & $0.17^{\text {ns }}$ & $0.23^{\text {ns }}$ \\
Plot & $11.96^{* * *}$ & $12.20^{* * *}$ & $6.65^{* *}$ & $6.65^{* *}$ & $1.00^{\text {ns }}$ & $4.25^{*}$ & $2.72^{\text {ns }}$ \\
Site* & & $1.27^{* *}$ & $1.33 \mathrm{~ns}$ & $4.73^{\star}$ & $0.02^{\text {ns }}$ & $0.56^{\text {ns }}$ & $0.29^{\text {ns }}$ \\
\hline
\end{tabular}

2015), Atriplex canescens, Suaeda vera (Ayyappan and Ravindran, 2014), Calendula officinalis L. (Hristozkova et al. 2016), Marrubium vulgare (Belabed et al. 2014), Limbarda crithmoides subsp. longifolia and Dittrichia viscosa (Turnau et al. 2010). The floristic survey showed that DM site has more diversified plant species than LT (34 plant species in DM, and 28 in LT), while the flora has not been affected, despite the high $\mathrm{Pb}, \mathrm{Cr}$ and $\mathrm{Cd}$ concentrations in the soil, due to the presence of different native heavy metal accumulator plants. Soil salinity values were heterogeneous, and interestingly, salinity is the critical factor controlling the distribution of plant communities within the study sites, corroborating those of several Algerian wetland studies (Aliat et al. 2016, Chenchouni 2017). The current study shows that the levels of $\mathrm{Pb}$ (270-820 ppm) in DM and (101-278 ppm) in LT), Cd (1.84-8 ppm in DM and 1.79-3.17 in LT), Cu (118 ppm in DM) and Cr (97.14-508.87 ppm in DM) recorded exceeded AFNOR NFU 44-041 reference values (100, 2 and 150 ppm, respectively), and are higher than those reported by several authors of wetland soil studies (Teuchies et al. 2013, Belabed et al. 2017, Esmaeilzadeh et al. 2017). In addition, nickel and zinc concentrations in DM and LT soils in the present study are homogeneous and vary only slightly. They do not exceed the reference values, but the highest values for $\mathrm{Ni}$ and $\mathrm{Cu}$ are recorded in DM and the highest $\mathrm{Zn}$ value is found in LT. Similar values were reported in Algerian wetlands near to industries, including El- Hadjar iron and steel complex (Belabed et al. 2017, Louhi et al. 2012). On the other hand, 
PCA test showed a good correlation between the different total metal contents except for Zn, suggesting a common origin as confirmed by Carrasco et al. (2006). The presence of these metals in stations located close to industrial areas confirms their anthropogenic origin. According to Vardanyan et al. (2008), very high local concentrations of metals often occur as a result of a strong reducing environment coupled with industrial and municipal discharges.

The variation of MTE between sites was significant at $\mathrm{P}$ $<0.001$. However, their variation between plots was not significant, except for $\mathrm{Cr}, \mathrm{Cu}$, and $\mathrm{Zn}$ which decreased inversely with salinity, indicating that they might arise from flood water. Elevated metal $(\mathrm{Pb}, \mathrm{Zn}$, and $\mathrm{Cr})$ contents and toxic phosphate levels in DM are likely to impose toxic effects for plant establishment in addition to other constraints, but it is difficult to prove MTE toxicity because it depends on their soil availability which is generally reduced.

Our data also showed higher mycorrhizal frequency in Asteraceae varied with particular species, that confirms several previous studies, showing high total colonization in Centaurea stoebe (Gucwa-Przepiora and Blaszkowski 2007) and Calendula officinalis (Hristozkova et al. 2016). These results may explain the considerable effectiveness of Calendula officinalis and $M$. vulgare extensively mycorrhized in the phytoremediation of heavy metals (Hristozkova et al. 2016).

As the genus Asphodelus is known to form AM (Cavagnaro et al. 2001), we detected in our study the presence of AM, Ectomycorrhizae and DSE in A. tenuifolius roots. The microsclerotes (7.5\%) and sporangia (27.5\%) observed are reported here for the first time. This seems to be a kind of plant species adaptation to environmental stress caused by salinity, inundation and metal pollution.

In this study, Tamarix sp. was not mycorrhized but Bencherif et al. (2015) reported 16 to $65 \%$ of AM frequency in Tamarix articulata Vahll in Algerian saline soils. No mycorrhization was found in Salicornia patula and Arthrocnemum macrostachyum roots which confirm the results of Landwehr et al. (2002), in saline, sodic and gypsum soils. Arbuscule rates in Amaranthaceae were very low $(\mathrm{A}<12 \%)$, like those reported by Becerra et al. (2016). Plenchette and Duponnois (2005) hypothesized about the existence of a third AM morphological type with no arbuscules in the Amaranthaceae family.

The high incidence ( $>50 \%$ ) of DSE in the present study is in accordance with several reports on their great abundance in highly stressed ecosystems (Schmidt et al. 2008), as in wetlands (Kumar and Muthukumar 2014) and in heavily polluted soils (Čevnik et al. 2000). Additionally, the findings showed that DSE colonization is positively correlated with $\mathrm{Cr}$ and $\mathrm{Cu}$ concentration in soil, indicating that these fungal endophytes infect plant root systems occupying highly $\mathrm{Cr}$ and $\mathrm{Cu}$ stressed areas, or that plants might utilize them as an adaptation mechanism to resist abiotic stress in $\mathrm{Cr}$ and $\mathrm{Cu}$ polluted soil, due to their role in the accumulation of some trace elements, and the amelioration of the growth of some plants (Wang et al. 2016).
DSE correlated negatively with mycorrhizal frequency in the investigated plant root systems, indicating the important competitive and antagonistic interaction between the two fungal endophytes, like those found by (Kandalepas et al. 2010), confirming our result. According to the same authors, DSE could be more resistant to adverse environmental conditions than mycorrhizal fungi by being either more competitive in disturbed or moderately polluted soils or better equipped to survive.

The distribution of AM fungal species of the current study showed a great AMF species richness, recorded in both DM and LT (28 and 20, respectively). These results are comparable to those of Wang et al. (2011) (23 phylotypes) and de Marins et al. (2009) (27 morphotypes). The dominance of Glomeraceae and Acaulosporaceae was also reported by previous studies of wetlands (Sun et al. 2016). This dominance is owing to their ability to propagate via mycelial fragments, mycorrhizal root fragments and spore germination (Yang et al. 2015), and adaptation to stressful conditions of soil contamination with heavy metals compared with other AMF species metals (Lopes Leal et al. 2016). Septoglomus constrictum, Funneliformis mosseae and Funneliformis geosporum isolated from study sites were also isolated in Algerian saline areas (Bencherif et al. 2015). These fungi and others encountered in our investigation (Cl. claroideum, A. mellea and $A r$. undulata) were also recorded in saline or heavy metal-polluted areas (Hammer et al. 2011).

AM frequency cannot be affected by spore density, unlike species richness, and hence the infective AMF are not automatically those producing a greater proportion of spores, but an increase in fungal colonization results from a greater AMF species diversity in root systems. These results are in line with those of de Marins et al. (2009) done in wetlands and hence they confirmed that spores occur both in the rhizosphere of macrophytes whose roots were internally colonized by AMF and in non-colonized macrophytes. However, mycorrhizal roots and extraradical mycelia in the soil also could be involved in plant root infection.

On the other hand, salinity strongly affects AM plant status and species richness, indicating that mycorrhizal colonization and diversity are indeed reduced with increasing salt levels, as with those previously found by Füzy et al. (2008). No correlation is observed between spore density and salinity, because they are halotolerant and more adapted to soil salt levels in these areas. This result suggest that the soil salt concentration is not sufficiently high to affect negatively the sporulation in these AMF species and that probably they develop their own ability to survive and naturally occur in saline environments (Hammer et al. 2011). Inversely there are reports of low AMF spore density in saline areas (Barrow et al. 1997) while Aliasgharzad et al. (2001) suggest that higher fungal spore density in saline soils may be due to the fact that sporulation is stimulated under salt stress, and this means the possibility of producing spores by AMF under low root-colonization levels in severe saline conditions. 
In addition, heavy metal pollution rates including $\mathrm{Pb}, \mathrm{Ni}$, $\mathrm{Cu}$, and $\mathrm{Cr}$ concentrations disturb spore density but not mycorrhizal status, except for $\mathrm{Cr}$ which may inhibit root hyphal colonization. These results are in agreement with those of Vogel-Mikuš et al. (2005), indicating that the elevated concentrations of $\mathrm{As}, \mathrm{Pb}, \mathrm{Zn}, \mathrm{Cd}$, and $\mathrm{Cu}$ exerted harmful effects on AMF spore numbers in polluted plots. Heavy metals have been reported to reduce, delay, or even eliminate AMF colonization and spore density at heavy metal polluted sites (Wei et al. 2015). Salinity seems to affect AMF diversity and infectivity, but not sporulation, which is more influenced by heavy metal pollution. MTE may play a major role in the distribution of spore density.

In sum, this is the first report on Algerian AM diversity in saline and contaminated wetlands with heavy metals. It revealed a specific plant community and environmental stress, including high salinity as well as trace element pollution. The salinity gradient and ETM pollution were found to be the dominant factors affecting AM community struc-

\section{References}

Aliasgharzad, N., Saleh Rastin, N., Towfighi, H., Alizadeh, A., 2001: Occurrence of arbuscular mycorrhizal fungi in saline soils of the Tabriz Plain of Iran in relation to some physical and chemical properties of soil. Mycorrhiza 11, 119-122.

Aliat, T., Kaabeche, M., Khomri, H., Nouri, L., Neffar, S., Chenchouni, H., 2016: A pedological characterisation of some inland wetlands and ramsar sites in Algeria. Land Degradation and Development 27, 693-705.

Ayyappan, D., Ravindran, K.C., 2014: Potentiality of Suaeda monoica Forsk. A salt marsh halophyte on bioaccumulation of heavy metals from tannery effluent. International Journal of Modern Research and Reviews 2, 267-274.

Ban, Y., Jiang, Y., Li, M., Zhang, X., Zhang, S., Wu, Y., Xu, Z., 2017: Homogenous stands of a wetland grass living in heavy metal polluted wetlands harbor diverse consortia of arbuscular mycorrhizal fungi. Chemosphere 181, 699-709.

Barrow, J.R., Havstad, K.M., McCaslin, B.D.,1997: Fungal root endophytes in fourwing saltbush, Atriplex canescens, on arid rangelands of southwestern USA. Arid Soil Research and Rehabilitation 11, 177-185.

Becerra, A., Bartoloni, N., Cofré, N., Soteras, F., Cabello, M., 2016: Hongos micorrícico-arbusculares asociados a Chenopodiaceae en dos ambientes salinos de Córdoba. Boletin de La Sociedad Argentina de Botanica 51, 5-13.

Belabed, B.-E., Meddour, A., Samraoui, B., Chenchouni, H., 2017: Modeling seasonal and spatial contamination of surface waters and upper sediments with trace metal elements across industrialized urban areas of the Seybouse watershed in North Africa. Environmental Monitoring and Assessment 189, 265.

Belabed, S., Lotmani, B., Romane, A., 2014: Assessment of metal pollution in soil and in vegetation near the wild garbage dumps at Mostaganem region. Journal of Materials and Environmental Science 5, 1551-1556.

Bencherif, K., Boutekrabt, A., Fontaine, J., Laruelle, F., Dalpè, Y., Anissa, L.H.S., 2015: Impact of soil salinity on arbuscular mycorrhizal fungi biodiversity and microflora biomass associated with Tamarix articulata Vahll. rhizosphere in arid and semi-arid Algerian areas. Science of the Total Environment 533, 488-494.

Benziane, A.B., 2013: Le système aquifère de la Grande Sebkha d'Oran : considérations géologiques et hydrogéologiques The aq- tures. Both AMF diversity and infectivity decreased with the increase in soil salinity, while AM fungal sporulation rates were attenuated by MTE augmentation. This native flora is naturally adapted to soil stress and associated with AM and endophytic fungi. This is why it is essential to fight ETM pollution in these Algerian wetlands, to protect well-adapted plant species that stay in these disturbed ecosystems, and also to select effective halophytes that are associated with appropriate AM fungi from these polluted wetlands for their use in phytoremediation.

\section{Acknowledgements}

This research did not receive any specific grant from funding agencies in the public, commercial, or not-forprofit sectors. We gratefully thank to Professor M. Kaid Harche and Dr M. Bouzouina for their helpful ideas and for ETM analysis, and Dr. N.E. Yahia for his support in statistical analysis.

uifer system of the Great Sebkha of Oran: Geological and hydrogeological considerations. Bulletin de l'Institut Scientifique, Rabat, Section Sciences de la Terre 35, 77-92.

Boucheker, A., Samraoui, B., Prodon, R., Amat, J.A., Rendón-Martos, M., Baccetti, N., Béchet, A., 2011: Connectivity between the Algerian population of Greater Flamingo Phoenicopterus roseus and those of the Mediterranean basin. Ostrich 82, 167-174.

Bouldjedri, M., De Bélair, G., Mayache, B., Muller, S.D., 2011: Threats to and conservation of North African wetlands: The case of the Ramsar site of Beni-Belaid (NE Algeria). Comptes Rendus Biologies 334, 757-772.

Bradai, L., Bouallala, M., Bouziane, N.F., Zaoui, S., Neffar, S. Chenchouni, H., 2015: An appraisal of eremophyte diversity and plant traits in a rocky desert of the Sahara. Folia Geobotanica 50, 239-252.

Brundrett, M., Bougher, N., Dell, B., Grove, T., Malajczuk, N., 1996: Working with mycorrhizas in forestry and agriculture. ACIAR Monograph. The Journal of Biological Chemistry 32, 173-193.

Cabral, L., Soares, C.R.F.S., Giachini, A.J., Siqueira, J.O., 2015: Arbuscular mycorrhizal fungi in phytoremediation of contaminated areas by trace elements: mechanisms and major benefits of their applications. World Journal of Microbiology and Biotechnology 31, 1655-1664.

Carrasco, L., Caravaca, F., Álvarez-Rogel, J., Roldán, A., 2006: Microbial processes in the rhizosphere soil of a heavy metals-contaminated Mediterranean salt marsh: A facilitating role of AM fungi. Chemosphere 64, 104-111.

Cavagnaro, T.R., Smith, F.A., Lorimer, M.F., Haskard, K.A., Ayling, S.M., Smith, S.E., 2001: Quantitative development of Paris-type arbuscular mycorrhizas formed between Asphodelus fistulosus and Glomus coronatum. New Phytologist 149, 105-113.

Chenchouni, H., 2017: Edaphic factors controlling the distribution of inland halophytes in an ephemeral salt lake "Sabkha ecosystem" at North African semi-arid lands. Science of the Total Environment 575, 660-671.

Chenchouni, H., Si Bachir, A., 2010: Zones humides et biodiversités-Classification et typologie des zones humides du Bas-Sahara algérien et caractérisation de la biocénose du Lac Ayata (Vallée d'Oued Righ). Sarrebruck: Editions Universitaires Européennes, 137. 
Cornwell, W.K., Bedford, B.L., Chapin, C.T., 2001: a Phosphorus - poor wetland and mycorrhizal. American Journal of Botany $88,1824-1829$.

Čevnik, M., Jurc, M., Vodnik, D., 2000: Filamentous fungi associated with the fine roots of Erica herbacea L. from the area influenced by the Žerjav lead smelter (Slovenia). Phyton, Annales Rei Botanicae, Horn 40, 61-64.

D’Souza, J., Rodrigues, B. F., 2013: Biodiversity of Arbuscular Mycorrhizal (AM) fungi in mangroves of Goa in West India. Journal of Forestry Research 24, 515-523.

de Marins, J.F., Carrenho, R., Thomaz, S.M., 2009: Occurrence and coexistence of arbuscular mycorrhizal fungi and dark septate fungi in aquatic macrophytes in a tropical river-floodplain system. Aquatic Botany 91, 13-19.

Dobignard, A., Chatelain, C., 2010-2013: Index synonymique flore d'Afrique du Nord, 1-5. Conservatoire et Jardin botaniques, Genève.

Domínguez-Beisiegel, M., Castañeda, C., Mougenot, B., Herrero, J., 2016: Analysis and mapping of the spectral characteristics of fractional green cover in saline wetlands (NE Spain) using field and remote sensing data. Remote Sensing 8, 590.

Esmaeilzadeh, M., Karbassi, A., Bastami, K.D., 2017: Antioxidant response to metal pollution in Phragmites australis from Anzali wetland. Marine Pollution Bulletin 119, 376-380.

Füzy, A., Biró, B., Tóth, T., Hildebrandt, U., Bothe, H., 2008: Drought, but not salinity, determines the apparent effectiveness of halophytes colonized by arbuscular mycorrhizal fungi. Journal of Plant Physiology 165, 1181-1192.

Gerdemann, J.W., Nicolson, T.H., 1963: Spores of mycorrhizal Endogone species extracted from soil by wet sieving and decanting. Transactions of the British Mycological Society 46, 235-244.

Ghodbani, T., Amokrane, K., 2013: La zone humide de la Macta: un espace à protéger sur le littoral ouest de l'Algérie. Physio-Géo 7, 139-155.

Gucwa-Przepiora, E., Blaszkowski, J., 2007: Arbuscular mycorrhiza of plants spontaneously colonizing the soda heap in Jaworzno (Southern Poland). Acta Societatis Botanicorum Poloniae 76, 69-74.

Hammer, E.C., Nasr, H., Pallon, J., Olsson, P.A., Wallander, H., 2011: Elemental composition of arbuscular mycorrhizal fungi at high salinity. Mycorrhiza 21, 117-129.

Hristozkova, M., Geneva, M., Stancheva, I., Boychinova, M., Djonova, E., 2016: Contribution of arbuscular mycorrhizal fungi in attenuation of heavy metal impact on Calendula officinalis development. Applied Soil Ecology 101, 57-63.

ISO 11466, 1995: Soil quality - extraction of trace elements soluble in aqua regia. Geneva, Switzerland: International Organization for Standardization.

Jayachandran, K., Shetty, K.G., 2003: Growth response and phosphorus uptake by arbuscular mycorrhizae of wet prairie sawgrass. Aquatic Botany 76, 281-290.

Kandalepas, D., Stevens, K.J., Shaffer, G.P., Platt, W.J., 2010: How abundant are root-colonizing fungi in southeastern louisiana's degraded marshes? Wetlands 30, 189-199.

Kloke, A., 1979: Contents of arsenic, cadmium, chromium, fluorine, lead, mercury and nickel in plants grown on contaminated soil. United Nations-ECE Symposium, Geneva, 51-53.

Kumar, S., Muthukumar, T., 2014: Arbuscular mycorrhizal and dark septate endophyte fungal associations in South Indian aquatic wetland macrophytes. Journal of Botany 6, 1-14.

Landwehr, M., Hildebrandt, U., Wilde, P., Nawrath, K., Tóth, T., Biró, B., Bothe, H., 2002: The arbuscular mycorrhizal fungus Glomus geosporum in European saline, sodic and gypsum soils. Mycorrhiza 12, 199-211.

Lopes Leal, P., Varón-López, M., Gonçalves de Oliveira Prado, I., Valentim dos Santos, J., Fonsêca Sousa Soares, C.R., Siqueira, J.O., de Souza Moreira, F.M., 2016: Enrichment of arbuscular mycorrhizal fungi in a contaminated soil after rehabilitation. Brazilian Journal of Microbiology 47, 853-862.
Louhi, A., Hammadi, A., Achouri, M., 2012: Determination of some heavy metal pollutants in sediments of the Seybouse river in annaba, Algeria. Air, Soil and Water Research 5, 91-101.

Lutts, S., Lefèvre, I., 2015: How can we take advantage of halophyte properties to cope with heavy metal toxicity in salt-affected areas? Annals of Botany 115, 509-528.

Maire, R., 1952-1987: Flore de l’Afrique du Nord (Maroc, Algérie, Tunisie, Tripolitaine, Cyrénaïque et Sahara), 1-16. Le Chevalier, Paris.

Manousaki, E., Kalogerakis, N., 2011: Halophytes - an emerging trend in phytoremediation. International Journal of Phytoremediation 13, 959-969.

Mathieu, C., Pieltain, F., 2003: Analyse chimique des sols: Méthodes choisies. Tec\&Doc, Paris.

Megharbi, A., Abdoun, F., Belgherbi, B., 2016: Diversité floristique en relation avec les gradients abiotiques dans la zone humide de la macta (ouest d'algérie). Revue D’écologie (Terre et Vie) 71, 142-155.

Mesnoua, M., Mateos-N aranjo, E., Barcia-Piedras, J.M., Pérez-Romero, J.A., Lotmani, B., Redondo-Gómez, S., 2016: Physiological and biochemical mechanisms preventing Cd-toxicity in the hyperaccumulator Atriplex halimus L. Plant Physiology and Biochemistry 106, 30-38.

Millar, N.S., Bennett, A.E., 2016: Stressed out symbiotes: hypotheses for the influence of abiotic stress on arbuscular mycorrhizal fungi. Oecologia 182, 625-641.

Miller, S.P., Bever, J.D., 1999: Distribution of arbuscular mycorrhizal fungi in stands of the wetland grass Panicum hemitomon along a wide hydrologic gradient. Oecologia 119, 586-592.

Müller, G., 1979: Schwermetalle in den Sediments des Rheins Veränderungen seit 1971. Umschau in Wissenschaft und Technik 79, 778-783.

Neffar, S., Chenchouni, H., Beddiar, A., Redjel, N., 2013: Rehabilitation of degraded rangeland in drylands by prickly pear (Opuntia ficus-indica L.) plantations: effect on soil and spontaneous vegetation. Ecologia Balkanica 5, 63-83.

Oehl, F., Alves Da Silva, G., Goto, B.T., Sieverding, E., 2011: New recombinations in Glomeromycota. Mycotaxon 117, 429-434.

Phillips, J.M., Hayman, D.S., 1970: Improved procedures for clearing roots and staining parasitic and vesicular-arbuscular mycorrhizal fungi for rapid assessment of infection. Transactions of the British Mycological Society 55, 158-161.

Plenchette, C., Duponnois, R., 2005: Growth response of the saltbush Atriplex nummularia L. to inoculation with the arbuscular mycorrhizal fungus Glomus intraradices. Journal of Arid Environments $61,535-540$.

Quézel, P., Simonneau, P., 1960: Quelques aspects de la végétation des terrains salés des plaines sub-littorales de l'Oranie orientale. Essai sur les rapports entre les groupements végétaux et les teneurs en sels solubles. Direction de l'hydraulique et de l'équipement rural. Travaux des sections pédologie et agrologie, Bullentin 6, 27.

Redecker, D., Schüßler, A., Stockinger, H., Stürmer, S. L., Morton, J. B., Walker, C., 2013. An evidence-based consensus for the classification of arbuscular mycorrhizal fungi (Glomeromycota). Mycorrhiza 23, 515-531.

Roda, J.J., Díaz, G., Torres, P., 2008: Spatial distribution of arbuscular mycorrhizal fungi in the rhizosphere of the salt marsh plant Inula crithmoides L. along a salinity gradient. Arid Land Research and Management 22, 310-319.

Saint-Etienne, L., Paul, S., Imbert, D., Dulormne, M., Muller, F., Toribio, A., Bâ, A.M., 2006: Arbuscular mycorrhizal soil infectivity in a stand of the wetland tree Pterocarpus officinalis along a salinity gradient. Forest Ecology and Management 232, 86-89.

Samraoui, B., Bounaceur, F., Bouzid, A., Alioua, A., 2015: Lake Télamine in Algeria , a new breeding site of the Greater Flamingo Phoenicopterus roseus. Alauda 3, 235-238. 
Schmidt, S.K., Sobieniak-Wiseman, L.C., Kageyama, S.A., Halloy, S.R.P., Schadt, C.W., 2008: Mycorrhizal and dark-septate fungi in plant roots above 4270 meters elevation in the Andes and Rocky Mountains. Arctic, Antarctic, and Alpine Research 40, 576-583.

Simpson, E.H., 1949: Measurement of Diversity. Nature. 163: 688.

Sun, Z., Chen, J., Wang, X., Lv, C., 2016: Heavy metal accumulation in native plants at a metallurgy waste site in rural areas of Northern China. Ecological Engineering 86, 60-68.

Teuchies, J., Jacobs, S., Oosterlee, L., Bervoets, L., Meire, P., 2013: Role of plants in metal cycling in a tidal wetland: Implications for phytoremidiation. Science of the Total Environment 446, 146-154.

Trouvelot, A., Kough, J., Gianinazzi-Pearson, V., 1986: Mesure du taux de mycorhization VA d'un systeme radiculaire. Recherche de methods d'estimation ayant une signification fonctionnelle. In: Gianinazzi-Pearson, V. Gianinazzi, S. (eds.), Physiological and Genetical Aspects of Mycorrhizae, 217-221. INRA Press, Paris.

Tuheteru, F.D., Kusmana, C., Mansur, I., Iskandar., 2015: Response of lonkida (Nauclea orientalis L.) towards mycorrhizal inoculum in waterlogged condition. Biotropia 22, 61-71.

Turnau, K., Ostachowicz, B., Wojtczak, G., Anielska, T., Sobczyk, Ł., 2010: Metal uptake by xerothermic plants introduced into $\mathrm{Zn}$ $\mathrm{Pb}$ industrial wastes. Plant and Soil 337, 299-311.

Turner, S.D., Amon, J.P., Schneble, R.M., Friese, C.F., 2000: Mycorrhizal fungi associated with plants in ground-water fed wetlands. Wetlands 20, 200-204.

Vardanyan, L., Schmieder, K., Sayadyan, H., Heege, T., Heblinski, J., Agyemang, T., Breuer, J., 2008: Heavy metal accumulation by certain aquatic macrophytes from Lake Sevan (Armenia). Proceedings of Taal 2007: The 12th World Lake Conference. In: Sengupta M., Dalwani R. (eds.), International Lake Environment committee, Jaipur, Rajasthan, India, 1028-1038.
Vogel-Mikuš, K., Drobne, D., Regvar, M., 2005: Zn, Cd and Pb accumulation and arbuscular mycorrhizal colonization of pennycress Thlaspi praecox Wulf. (Brassicaceae) from the vicinity of a lead mine and smelter in Slovenia. Environmental Pollution $133,233-242$.

Wang, J.L., Li, T., Liu, G.Y., Smith, J.M., Zhao, Z.W., 2016: Unraveling the role of dark septate endophyte (DSE) colonizing maize (Zea mays) under cadmium stress: Physiological, cytological and genic aspects. Scientific Reports 6, 1-12.

Wang, Y., Huang, Y., Qiu, Q., Xin, G., Yang, Z., Shi, S., 2011: Flooding greatly affects the diversity of arbuscular mycorrhizal fungi communities in the roots of wetland plants. PLoS ONE 6(9), e24512.

Wei, Y., Chen, Z., Wu, F., Hou, H., Li, J., Shangguan, Y., Zeng, Q., 2015: Molecular diversity of arbuscular mycorrhizal fungi at a large-scale antimony mining area in southern China. Journal of Environmental Sciences 29, 18-26.

Wężowicz, K., Turnau, K., Anielska, T., Zhebrak, I., Goluszka, K., Blaszkowski, J., Rozpadek, P., 2015: Metal toxicity differently affects the Iris pseudacorus-arbuscular mycorrhiza fungi symbiosis in terrestrial and semi-aquatic habitats. Environmental Science and Pollution Research 22, 19400-19407.

Xu, Z., Ban, Y., Jiang, Y., Zhang, X., Liu, X., 2016: Arbuscular mycorrhizal fungi in wetland habitats and their application in constructed wetland: A Review. Pedosphere 26, 592-617.

Yang, F., Christie, P., Li, L.X., Dai, Y., Li, G.Z., Gai, J., 2010: A preliminary survey of arbuscular mycorrhizal fungi associated with marsh plants in Lhalu wetland, suburban Lhasa, south Tibet. Wetland Science 8, 28-36.

Yang, Y., Song, Y., Scheller, H.V., Ghosh, A., Ban, Y., Chen, H., Tang, M., 2015: Community structure of arbuscular mycorrhizal fungi associated with Robinia pseudoacacia in uncontaminated and heavy metal contaminated soils. Soil Biology and Biochemistry $86,146-158$. 